\title{
THE AUTHORITY OF THE MINISTER OF JUSTICE IN RELATION WITH THE PROSECUTORS, PROVIDED BY ARTICLE 132 PARAGRAPH (1) OF THE CONSTITUTION, IN THE CASE LAW OF THE CONSTITUTIONAL COURT
}

DOI: $10.47743 /$ rdc-2018-1-0005

Tudorel TOADER

Marieta SAFTA ${ }^{2}$

ttoader@uaic.ro

marietasafta@yahoo.com

\section{Abstract}

The Decision no. $358 / 2018^{3}$ by which the Constitutional Court has settled a legal conflict of a constitutional nature between the Minister of Justice and the President of Romania states on the interpretation of the phrase "under the authority of the Minister of Justice" contained in Article 132 (1) of the Constitution, according to which "Prosecutors operate in accordance with the principles of legality, impartiality and hierarchical control, under the authority of the Minister of Justice." We will summarize this decision, whose reasoning is structured on the following main coordinates:

Keywords: revocation of district attorney; constitutional legal conflict; constitutional loyalty; authorithy of the minister of justice; statement of Superior Council of Magistracy

\section{The european criminal justice systems vary and are anchored in their respective different legal cultures, without a uniform model existing}

\section{for all the states}

The Court emphasises that the institutional position of the Public Ministry in the system of exercising the public power and the status of the prosecutors are regulated

\footnotetext{
${ }^{1}$ Professor, PhD, University “A.I. Cuza” of Iași; Minister, Ministry of Justice; Judge of the Constitutional Court of Romania between 2006-2016; Member of the Venice Commission.

2 Associate Professor, PhD, Faculty of Law, "Titu Maiorescu" University of Bucharest; Secretary of State, Ministry of Justice; First Assistant-Magistrate of the Constitutional Court of Romania (seconded to the Ministry of Justice).

3 Published in the Official Gazette of Romania, Part I, no. 473 of 07 June 2018.
}

CONSTITUTIONAL NEWS 
at constitutional level and thus constitute purely internal matters of the Romanian State. The precise definition of the prosecutor's nature and role is a particularly complex issue ${ }^{4}$.

For this purpose, the Venice Commission showed that the European criminal justice systems vary and are anchored in their respective different legal cultures, without a uniform model existing for all the states; whilst Recommendation $\operatorname{Rec}(2000) 19$ of the Committee of Ministers of the Council of Europe allows a plurality of models, including models where the public ministry is part of or subordinated to the Government. Moreover, the Venice Commission has underlined that the independence or autonomy of the Public Ministry is, through its nature, not so categorical as that of the courts of justice.

The systems in which the Public Ministry is part of or subordinated to the Government meet the European standards, conditional on the existence of effective measures to safeguard the independence or autonomy of the Public Ministry and the non-intervention of the Government in specific/individual cases ${ }^{5}$.

In consequence, no international standards exist to impose the independence of the Public Ministry ${ }^{6}$.

\section{The intention of the originating constitution maker regarding}

\section{the regulation of the status of prosecutors and Public Ministry}

The Court has found that the actual regulation of the Art. 132 par. (1) of the Constitution wasn't change at the revision of the Constitution, in 2003. Consequently, the Court has to identify the intention of the originating constitution maker, alongside the underlying reasoning, in order to establish the content of these provisions ${ }^{7}$.

Thus, the Court acknowledges that, in the session of the National Constituent Assembly, the Rapporteur of the Commission writing the draft of the Chapter on the

\footnotetext{
${ }^{4}$ The European Commission for Democracy through Law (Venice Commission), in its Opinion no. 169/2001 on the Law amending the Constitution of Romania, adopted in its 51st plenary session of 5-6 July 2002, Para. 59.

${ }^{5}$ See Opinion no. 892/2017 on the Law on the Public Ministry from Polonia, as amended, adopted by the Venice Commission in its 113th plenary session of 8-9 December 2017, Paragraphs 27 and 28, the Joint Opinion no. 791/2014 on the draft Law on the Public Ministry in the republic of Moldova, prepared by the Venice Commission, Department for Human Rights of the General Directorate for Human Rights and Rule of Law of the Council of Europe and by the Office of Democratic Institutions and Human Rights of the Organisation for Security and Cooperation in Europe (OSCE), adopted by the Venice Commission in its 102nd plenary session of 20-21 March 2015, Paragraph 28, as well as the Report of the Venice Commission on the independence of the judiciary, Part II: the Public Ministry, adopted in its 85th plenary session of 17-18 December 2010, Paragraph 7.

${ }^{6}$ Opinion no. 709/2012 on the drafts to amend the Law on the Public Ministry, adopted by Venice Commission, in its 94th plenary session of 8-9 March 2013, Paragraph 20.

7 Regarding the interpretation of legal rules, see Decision no. 619 of 11 October 2016, published in the Official Gazette of Romania, Part I, no. 6 of 4 January 2017, Para. 30, and Decision no. 61 of 7 February 2017, published in the Official Gazette of Romania, Part I, no. 219 of 30 March 2017, Para. 36.
} 
Judicial authority of the Constitution of Romania, said: "In work of the Commission, during the debates, three solutions have been on the status of the Public Ministry: 1. Keeping the existing system of Procurators, as an independent institution in the State, a system that we come across in all the former socialist states and in Portugal. 2. Subordinating the Public Ministry directly to the Government of Romania. 3. Subordinating this institution to the Minister of Justice. This last option was selected, since it responds to our traditions and corresponds to the international practice in the matter"8.

The Court has also noted that, in the draft Constitution, the status of prosecutors was regulated thus: "Prosecutors operate in compliance with the principles of legality, impartiality and hierarchical control, under the administrative authority of the Minister of Justice". The Commission writing the draft of the Constitution of Romania admitted an amendment to this text and eliminated the term "administrative", giving the following reasoning: "to ensure the responsibility of the Minister of Justice regarding the entire activity of the Public Ministry, it is necessary that his/her authority be not limited to the purely administrative aspect. Otherwise, reducing this authority exclusively to its administrative aspects, the accountability for the work of the prosecutors that the Minister has towards the Parliament and Government is implicitly reduced"9. The Court also acknowledges that an amendment was formulated that the prosecutors should be under the authority of the General Prosecutor; however, the Commission explicitly rejected this amendment, reasoning that "The subordination of the Public Ministry to the Ministry of Justice is a political decision of the Constituent Assembly"10. It was also proposed that the Procurators Office be independent or that the prosecutors be under the authority of the Superior Council of Magistracy, amendments that were explicitly rejected ${ }^{11}$.

We have also to mention that Professor Antonie Iorgovan, in his work Odiseea Constituției ${ }^{12}$, held on this point that "finally, in view of the amendments to the draft Constitution, there was a general compromise formula that can be expressed through two ideas: a) The Public Ministry, made up of prosecutor's offices, which are constituted by the courts, is a "dimension" of the "judicial authority" (together with the Courts and the Superior Council of Magistracy); and b) the prosecutors operate on the basis of the hierarchical control principle under the authority of the Minister of Justice".

\footnotetext{
${ }^{8}$ See Geneza Constituției României — Lucrările Adunării Constituante, Ed. R.A. Official Gazette, Bucharest, 1998, page 567.

${ }^{9}$ See Geneza Constituției României - Lucrările Adunării Constituante, Ed. R.A. Official Gazette, Bucharest, 1998, pages 667-668.

${ }^{10}$ See Geneza Constituției României - Lucrările Adunării Constituante, Ed. R.A. Official Gazette, Bucharest, 1998, page 668 .

11 See Geneza Constituției României - Lucrările Adunării Constituante, Ed. R.A. Official Gazette, Bucharest, 1998, pages 595-596.

12 Uniunii Vatra Românească Publishing House, Târgu Mureș, 1998, p. 43.
}

CONSTITUTIONAL NEWS 
3. The case-law of the Constitutional Court on the status of prosecutors up to Decision No. 358/2018

According to Art. 131 Para. (1) ${ }^{13}$ of the Constitution, prosecutors operate under the authority of the minister of justice, which, of course, entails a subordination of all prosecutors, since the constitutional text does not discriminate. On the other hand, art. 130 Para. (2) [turned into Art. 131 Para. (2)] of the Constitution stipulates that the Public Ministry exercises its authority through prosecutors set up in prosecutors' offices, in compliance with the law. This being the situation, it means that the law may specify the forms in which the authority of the Minister of Justice over prosecutors is manifested, including his right to issue orders directly to prosecutors, with a view to ensuring compliance with and enforcement of the law. The claim that this authority is only administrative made in the notice submitted by the group of members of the Chamber of Deputies is contrary to the constitutional text, following the Constituent Assembly's acceptance of an amendment that eliminated the restriction from the draft Constitution that limited the authority of the Minister of Justice only to administrative matters"14.

The fact that the provisions on the Public Ministry are placed in the Constitution in the Chapter concerning the "Judicial authority" cannot lead, from the perspective of the matter submitted for settlement, to any other conclusion, given that this situation does not transform the Public Ministry and its units into courts of law that, according to the Constitution, administrate justice. In the Chapter on "Judicial authority" the provisions of Art. 131 [turned Art. 132] of the Constitution are also placed, which, in Para. (1), stipulate that prosecutors carry out their activity in accordance with the principle of legality, impartiality and hierarchical control, under the authority of the Minister of Justice. It is undoubted that the Minister of Justice is a representative of the executive. Without going into the doctrine controversies on the nature of the Public Ministry, this constitutional text undoubtedly indicates a relationship of the institution of the Public Ministry's with the executive power, relationship caused by the fact that the latter permanently and continuously represents the interests of the society and, according to Art. 130 Para. (1) [turned Art. 131 Para. (1)] of the Constitution, within the judicial activity, the Public Ministry represents the general interests of the society, and defend legal order, as well as the citizens' rights and freedoms"15.

It is true that, according to the Constitution, the Public Ministry is part of the "judicial authority». However, it represents a special category of magistrates that do not discharge duties of jurisdictional nature. Pursuant to Art. 131 Para. (1) of the

\footnotetext{
${ }_{13}$ Turned into Art. 132 Para. (1) following the republication of the Constitution (with the consequence of renumbering the texts) in the Official Gazette of Romania, Part I, no. 767 of 31 October 2003.

${ }^{14}$ Decision no. 339 of 18 July 1997, published in the Official Gazette of Romania, Part I, no. 170 of 25 July 1997.

15 Decision no. 96 of 24 September 1996, published in the Official Gazette of Romania, Part I, no. 251 of 17 October 1996.
} 
Constitution, prosecutors operate "under the authority of the minister of justice», a body essentially executive, thus, by way of consequence, being themselves agents of the executive authority"16.

As stated in the case law of the Constitutional Court after the revision of the Constitution in 2003, the Public Ministry is a part of the judiciary, and not of the executive or civil service, and the principle of hierarchic control is the expression of the consistency in action of the members of the Public Ministry, a supplementary safeguard for the compliance with the principles of legality and impartiality in the judicial work"17.

The prosecutors [...], for whom the Constitution establishes the hierarchic control, and who carry out their activity under the authority of the Minister of Justice $^{18}$, are not a part of the judicial power, but of the judicial authority, yet, given their close connection with the administration of justice, the constituent law maker chose that the Public Ministry be not a part of the executive authority, and for this reason the activity of the prosecutors, materialised in the criminal investigation phase or the role they play in the trial phase of the criminal/civil lawsuit, as the case may be, are not under Parliamentary control, their activity being carried out under the authority of the Minister of Justice"19.

The Public Ministry was instated by Art. 131 and 132 of the Constitution of Romania as a magistracy component of the judicial authority, having the role of representing the general interests of the society and defending the rule of law and the citizens' rights and freedoms in the judicial activities"20.

Considering the bicephalous character or the executive authority, the law maker opted for a procedure [in the matter of appointment of prosecutors in management positions - n.n.] whereby the Government and the President should work together. Nevertheless, the central role in this equation is played by the Minister of Justice, under whose authority the prosecutors set up in prosecutors' office operate. The President of Romania has no explicit constitutional responsibility that might justify a right of veto in this matter. Therefore, if the organic law maker chose such a procedure for the appointment [appointment proposal by the Minister of Justice, opinion of the

\footnotetext{
${ }^{16}$ Decision no. 73 of 4 June 1996, published in the Official Gazette of Romania, Part I, no. 255 of 12 October 1996, or Decision no. 259 of 24 September 2002, published in the Official Gazette of Romania, Part I, no. 770 of 23 October 2002.

${ }^{17}$ See, in this matter, Decision no. 1. 503 of 18 November 2010, published in the Official Gazette of Romania, Part I, no. 8 of 5 January 2011, Decision no. 385 of 13 April 2010, published in the Official Gazette of Romania, Part I, no. 317 of 14 May 2010, Decision no. 307 of 5 June 2014, published in the Official Gazette of Romania, Part I, no. 579 of 4 August 2014, Para. 27.

${ }^{18}$ Art. 132 Para. (1) of the Constitution.

${ }^{19}$ See Decision no. 430 of 21 June 2017, published in the Official Gazette of Romania, Part I, no. 655 of 9 August 2017, par. 34, and Decision no. 206 of 3 April 2018, published in the Official Gazette of Romania, Part I, no. 351 of 23 April 2018, Para. 108.

${ }^{20}$ Decision no. 866 of 28 November 2006, published in the Official Gazette of Romania, Part I, no. 5 of 4 January 2007, and Decision no. 924 of 1 November 2012, published in the Official Gazette of Romania, Part I, no. 787 of 22 November 2012, pct. 7. 2. 2.
} 
Superior Council of Magistracy and appointment by Presidential Decree], maintaining a Presidential veto limited to turning down one proposal only for appointment in the management positions stipulated in Art. 54 Para. (1) of the Law, he complied with the constitutional role of the Minister of Justice in relation with the prosecutors, the President being conferred the authority to appoint in consideration of the solemnity of the action and the need for permanent collaboration and cooperation in the bicephalous executive"21.

The authority that the Minister of Justice exercises over prosecutors has no connection with the judicial work that a prosecutor carries out specifically in a criminal case, but pertains to the work of the Public Ministry in its entirety, in exercising its role to represent the general interests of the society and to defend the rule of law and the citizens' right and freedoms"22. "The constituent law maker intended to create a status of prosecutors that might allow them to remain equidistant from the work of the legislative and of the executive [see in this matter Decision no. 45 of 30 January 2018, Paragraph 168].

\section{The case law of the European Court of Human Right invoked} in Decision no. 358/2018

The European Court of Human Rights pointed out that, on the grounds of Art. 6 Paragraph 1 of the Convention for the Protection of Human Rights and Fundamental Freedoms, in Romania, prosecutors, acting as representatives of the Public Ministry, subordinate first to the General Prosecutor and then to the Minister of Justice, do not meet the requirement of independence in relation to the executive power; or, the independence from the executive is included among the safeguards entailed by the notion of "magistrate", pursuant to Art. 5 Paragraph 3 of the Convention; Furthermore, this case law of the European Court of Human Rights was also reflected in the case law of the Constitutional Court ${ }^{23}$.

In consequence, prosecutors cannot invoke a position of independence, as judges can, regarding whom Art. 124 Para. (3) explicitly provides that "Judges shall be independent and subject only to the law", since their activity is carried out under hierarchical control and under the authority of the Minister of Justice. For this purpose, the Venice Commission pointed out that, in a democratic context, the judicial policy criminal or civil - of a state is determined by the Government, an expression of the

\footnotetext{
${ }^{21}$ Decision no. 45 of 30 January 2018, Para. 165.

${ }^{22}$ Decision no. 136 of 20 March 2018, published in the Official Gazette of Romania, Part I, no. 383 of 4 May 2018, Para. 62.

${ }^{23}$ Judgment of 22 May 1998, issued in the Case Vasilescu vs. Romania, Paragraphs 40 and 41, of Judgment of 3 June 2003, issued in the Case Pantea vs. Romania, Paragraph 238 - See in this matter Decision no. 629 of 8 October 2015, published in the Official Gazette of Romania, Part I, no. 868 of 20 November 2015, Paragraph 17.
} 
The autority of the Minister of Justice in relation with the prosecutors...

Parliamentary majority. This policy should be implemented by the gents of the Government, namely the prosecutors, so that the exigencies on the full independence of the judges do not apply to the same extent to prosecutors ${ }^{24}$. Furthermore, the Venice Commission reiterated that the Public Ministry does not necessarily need to be independent, it being preferable that it be dependent on the Ministry of Justice ${ }^{25}$.

\section{Comparative law elements invoked in Decision no. 358/2018}

A similar situation is found in France, where, according to Art. 5 of Ordinance no. 58-1270 of 22 December 1958, magistrates from the prosecutors' offices are placed under the guidance and control of their hierarchic supervisors and under the authority of the minister of justice, and their independence refers to the free exercise of their actions in front of jurisdictions; moreover, this independence must be reconciled with the prerogatives of the Government and cannot provide the same safeguards to the magistrates from the prosecutors' office as those applicable to sitting magistrates ${ }^{26}$.

Furthermore, in Germany, according to Art. 147 of the Law on the forming of courts, the federal minister of justice has the right to supervise and guide the general federal prosecutor and the federal prosecutors, and the members of the prosecutors' office must conform to the official guidance provided by their superiors ${ }^{27}$.

\section{Conclusions and development of interpretation of the constitutional} reference text by Decision no. 358/2018

- The Court found that the Public Ministry is not part of the judicial power, but of the judicial authority, these being different concepts in their essence. Also, the Public Ministry does not have an independent position in relation to executive power/authority.

Though it is not part of the executive power or authority, the Public Ministry does not have an independent position in relation to them, since the Constitution is very clear, the activity of the prosecutors being placed under the authority of the Minister of Justice. Furthermore, as already shown, when the Constitution texts were developed, an amendment was rejected expressis verbis that provided for the independent character of the Public Ministry within the organisation of the public power, so that the

\footnotetext{
24 Opinion no. $169 / 2001$ on the Law to revise the Constitution of Romania, adopted in the $51^{\text {st }}$ plenary session of 5-6 July 2002, Paragraphs 60 and 61.

${ }^{25}$ Supplementary Opinion no. 169/2001 on the Law to revise the Constitution of Romania, adopted in its 52 ${ }^{\text {nd }}$ plenary session of 18-19 October 2002, Paragraph 23.

${ }^{26}$ See Decision of the French Constitutional Council no. 2017-680 QPC of 8 December 2017, Paragraph 9.

${ }^{27}$ Art. 146 of the same Law.
} 
will of the originating Constitution maker cannot be ignored and violated, who did not want to confer such an institutional position. Consequently, the interpretation of the constitutional text naturally follows the intention of the Constitutional law maker explicitly transposed in regulations in the shape of placing the activity of the prosecutors under the authority of the minister of justice.

- The Minister of Justice has full competence in terms of authority over prosecutors, limited only by explicit constitutional provisions, namely those concerning the appointment as prosecutor and application of disciplinary actions.

The Court also acknowledges that the authority of the Minister of Justice is not administrative; on the contrary, he has full competence in terms of authority over prosecutors. This full jurisdiction is only limited by explicit constitutional provisions, namely those concerning the appointment as prosecutor and application of disciplinary actions $^{28}$, these being ordered by the President of Romania, and, respectively, the Superior Council of Magistracy.

- In the given constitutional context, the authority of the Minister of Justice pertains to a power to decide in the management of prosecutors' career $^{29}$, but the manner in which the general criminal policy of the State is implemented ${ }^{30}$.

- Authority does not mean the hierarchical subordination of prosecutors to the Minister of Justice. The judicial activity actually carried out by a prosecutor, in a

\footnotetext{
${ }^{28}$ Art. 134 Para. (1) and (2) of the Constitution.

${ }^{29}$ E.g., according to Art. 69 Para. (1) and (2) of Law no. 304/2004, the Minister of Justice, when he/she deems necessary, of his/her own initiative or on request from the Superior Council of Magistracy, exercises control over the prosecutors through prosecutors specifically designated for this role by the general Prosecutor of the Prosecutor's Office attached to the High Court of Cassation and Justice or by the Chief Prosecutor of the National Anticorruption Department, by the Chief Prosecutor of the Department for Investigation of Organised Crime and Terrorism or by the Minister of Justice. The control consists of checking the management effectiveness, the manner in which the prosecutors discharge their duties and in which they maintain the relationships with the parties in cases and with other persons involved in the work of the prosecutors. The control cannot pertain to the measures ordered and solutions ruled by the prosecutor in the criminal investigation.

${ }^{30}$ See, mutatis mutandis, regarding the authority of the Minister of Justice in relation with the magistrates of the prosecutors' offices, both Art. 69 Para. (3) of Law no. 304/2004, according to which the Minister of Justice may ask the General Prosecutor of the Prosecutor's Office attached to the High Court of Cassation and Justice or the General Prosecutor of the National Anticorruption Department, as applicable, for information on the work of the prosecutors' offices and give them written guidance on the measures required to efficiently prevent and fight criminality, and the Decision of the French Constitutional Council no. 2017-680 QPC of 8 December 2017, Paragraph 11, according to which the authority of the Minister of Justice is manifested, in particular, by the exercising of a power to appoint and sanction, assumptions under which, on the one hand, the President of the Republic appoints the prosecutor on proposal from the Minister of Justice, cu with the endorsement of the competent division of the Superior Council of Magistracy, and, on the other hand, the Minister of Justice sanctions the prosecutor with the endorsement of the competent division of the Superior Council of Magistracy. At the same time, the Minister of Justice may address general instructions on criminal policy to the magistrates from the Public Ministry, in particular regarding the need to ensure the equality of the citizens in front of the law on the entire territory of the Republic.
} 
certain criminal case, has no connection with the authority of the minister of justice, and these are two distinct matters.

Per a contrario, should the constitutional text be interpreted as entailing the hierarchical subordination of the prosecutors to the Minister of Justice, this would lead to the situation that the originating constitutional law maker never envisaged and from which he wanted to get away, whereby the Minister of Justice would be the supreme chief of ten prosecutors to whom he could give orders and instructions on investigating crimes and delicts ${ }^{31}$. Therefore, the Court finds that the constitutional text enshrines an obvious element of discontinuity from the historic tradition in the matter of the relationship between the Minister of Justice and prosecutors.

Therefore, in the judicial activity, "in the solutions ordered, the prosecutor shall be independent, under the terms provided by law"32. The Venice Commission appreciated that the implementation of a policy does not mean under any circumstances the existence of precise orders given personally to prosecutors in a certain case file. Each of them maintains freedom of decision, but within the ministerial circular letters which set the main guidelines of the judicial policy of the states. A state cannot have multiple criminal policies at the latitude of the opinions or convictions of prosecutors, but only one criminal policy. Nevertheless, when appreciating how this policy should apply to individual cases, each prosecutor should be independent ${ }^{33}$. This is also the meaning of Decision no. 873 of 25 June $2010^{34}$, where the Court stipulated that one of the components of the independence of justice is the institutional component, which does not mean exclusively judges, but it covers the entire judiciary, an aspect which justifies the public service pension granted to prosecutors as well. Consequently, the Court finds that such a solution gives substance to the general European tendency - but not rule towards a more independent public ministry, compared to a public ministry which is subordinated or linked to the executive ${ }^{35}$.

Also, the same Art. 64 (1) stipulates that, by virtue of the hierarchical control which characterizes the activity of prosecutors "the orders of the hierarchically superior prosecutor, given in writing and according to law, are mandatory for all subordinated prosecutors". Thus, the indictment issued by the prosecutor is reviewed in terms of legality and soundness by the chief-prosecutor of the prosecutor's office or, as appropriate, by the general prosecutor of the prosecutor's office attached to the court

\footnotetext{
${ }^{31}$ See in this matter Art. 66 of the Law on the organisation of ministries of 2 August 1929, promulgated by Decree no. 2710/929 and published in the Official Gazette no. 169 of 2 August 1929.

${ }^{32}$ Art. 64 (2) first paragraph of Law no. 304/2004 on the organisation of the judiciary, republished in the Official Journal of Romania, Part I, no. 827 of 2 September 2005.

${ }^{33}$ Opinion of the Venice Commission no. 169/2001 on the law amending the Constitution of Romania, adopted at its 54th plenary session of 5-6 July 2002, paragraph 62.

${ }^{34}$ Published in the Official Journal of Romania, Part I, no. 433 of 28 June 2010.

35 See also the Joint Opinion no. 811/2015 on the draft amendments to the law on the Prosecutors' Office of Georgia, drafted by the Venice Commission, the Consultative Council of European Prosecutors of the Council of Europe and by the OSCE Office for Democratic Institutions and Human Rights, adopted by the Venice Commission at its 104 ${ }^{\text {th }}$ plenary session of 23-24 October 2015, paragraph 16.
} 
of appeal, and when the chief-prosecutor or the general prosecutor drafted the indictment, it shall be reviewed by the higher-ranking prosecutor. When drafted by a prosecutor from the Prosecutor's Office attached to the High Court of Cassation and Justice, the indictment is reviewed by the chief-prosecutor of the section, and if drafted by the latter, the review is performed by the general prosecutor of this prosecutor's office $^{36}$. Also, for exemplification purposes, the Court highlights that the complaints against measures taken or against acts carried out by the prosecutor or performed according to the orders issued by the prosecutor shall be settled by the chief-prosecutor of the prosecutor's office, by the general prosecutor of the prosecutor's office attached to the court of appeal, by the chief-prosecutor of the section of the Prosecutor's Office attached to the High Court of Cassation and Justice, according to Art. 339 of the Criminal Proceedings Code, and the complaint filed against decisions not to initiate prosecution and not to indict shall comply with the terms provided by Art. 340 and 341 of the Criminal Proceedings Code, thereby reaching the court of law, without the minister of justice having any power/jurisdiction for this purpose. Also, according to Art. 318 (10) of the Criminal Proceedings Code, "The order [of the prosecutor - our emphasis] to drop charges shall be reviewed in terms of legality and soundness by the chief-prosecutor of the prosecutor's office or, as appropriate, by the general prosecutor of the prosecutor's office attached to the court of appeal, and when the chief-prosecutor or the general prosecutor drafted the indictment, it shall be reviewed by the higher-ranking prosecutor. When drafted by a prosecutor from the Prosecutor's Office attached to the High Court of Cassation and Justice, the order shall be reviewed by the chief-prosecutor of the section, and if drafted by the latter, the review shall be performed by the general prosecutor of this prosecutor's office", and paragraph 12 of the same text stipulates that "The order to drop charges, reviewed according to paragraph (10), shall be communicated in copy, as appropriate, to the person who initiated the proceedings, to the parties, to the suspect, to the aggrieved person and to other interested persons and shall be submitted, for confirmation, within 10 days from the date of issuance, to the preliminary chamber judge from the court which, according to law, would have jurisdiction to judge the merits of the case".

- The authority of the Minister of Justice may be subjected, under the terms of the revocation of prosecutors from leading positions, to legal conditions, so that in itself it does not manifest indefinitely, arbitrarily, exclusively at its discretion.

In this respect, art. 54 paragraph (4) is related to art. 51 paragraph (2) of the Law no. 303/2004 on the cases of revocation. The Minister of Justice may propose, in the three hypotheses provided by law, the revocation of the chief prosecutor of the Prosecutor's Office attached to the High Court of Cassation and Justice, the first deputy and his deputy, the General Prosecutor of the National Anticorruption Directorate, his /

${ }^{36}$ Art. 328 (1), second and third paragraphs, Criminal Proceedings Code.

CONSTITUTIONAL LAW REVIEW 
her deputies, the Chief Prosecutors of these Prosecutor's Offices, as well as the Chief Prosecutor of the Directorate for the Investigation of Organized Crime and Terrorism Offenses and their deputies.

Under the procedural mechanism provided by the law ${ }^{37}$, the Minister of Justice has a central role. If the Minister of Justice has a wide margin of appreciation in the case of appointment to the post of prime minister, and the President of Romania has a limited margin, in the case of revocation, the Minister of Justice has a minimum margin of appreciation, since the limitations imposed by the law are extremely strict, and, under these circumstances, the President of Romania can only oppose his/her right to verify the lawfulness of the proposal, and may refuse it only if the proposal does not comply with the law, in which case the procedure will cease. Of course, no constitutional text opposes the existence of consultations between the two public authorities pursuant to Article 1 (5) and Article 80 (2), second sentence of the Constitution, however, since the entire procedure is conducted in the circumstances in which the discretionary competency/margin of appreciation of the minister of justice, who plays a central role in the proceedings, is minimal, the discretionary competency of the President can not be recognized in any way. Therefore, the President of Romania has only a competence related to this procedure, limited to verifying the conditions for the legality of the procedure. Otherwise, that is to say, where a minimum discretionary power, even of the public authority that plays a central role in the revocation procedure from the office of prosecutors, would be opposed to broad discretionary power of other public authorities, based on the idea of permanent cooperation and consultation, would mean an alteration of the authority of the Minister of Justice and a legal amendment of an express constitutional provision in the sense that, in reality, prosecutors would operate under the authority of the President of Romania. Moreover, the Court holds that the argument that two public authorities in the same procedure in which they are involved have the same powers cannot be upheld. In fact, each of these authorities has its own different powers, which means that in no case can two constitutional authorities exercise the same decision-making power/competence in the same procedure. And in this hypothesis, the solemnity of the act, the public debate and the transparency of the act of revocation imposed such a perfectly constitutional legislative solution. The proposal of the Minister of Justice to Revoke must be forwarded to the Superior Council of Magistrates - the Prosecutor's Section, where both the prosecutor to whom the revocation of the position of the Government and the Minister of Justice are being asked may expose their substantive arguments on the imputed aspects, defend / reconsider / nuance their point of view. The Superior Council of Magistracy - The Prosecutors Section issues an advisory opinion, which is a reference for the Minister of Justice in its decision to continue to support its revocation proposal. If he supports his proposal for revocation, the Minister of Justice sends it to the President of Romania; the

\footnotetext{
37 The proposal of the Minister of Justice, the Advisory Opinion of the Superior Council of Magistracy and the Act of the President of Romania.
} 
President of Romania will also be notified of the advisory opinion of the Superior Council of Magistracy. All of these, of a legal nature, cannot distort the constitutional authority of the Minister of Justice. It follows that the President of Romania cannot exercise his legal powers in a sense that would affect the constitutional text. That is why its competence is to control the legality of the measure, namely the revocation proposal, being unable to invoke aspects of opportunity or to carry out an evaluation of the activity of the Chief/General Prosecutor himself, as happened in this case. Thus, the decision-making power of the President of Romania is limited to the conditions of legality of the proposed revocation proposal.

The Court has stated also that There is neither the role of the President of Romania nor of the Constitutional Court to control this assessment ${ }^{38}$ because, in such a case, they would distort the role of the Minister of Justice and turn into authorities that control the way in which the Minister of Justice understands to exercise his minimal discretionary constitutional competence reflected in the evaluation. The Court also found that the Judgment of the Superior Council of Magistracy - the Prosecutor's Section, which has consultative value, may contain considerations regarding both the merits and the legality of the proposal. As long as the competence of the President of the Republic capitalizes only on the control of the legality of the revocation procedure, he cannot invoke as a ground for refusal the proposal of the Minister of Justice that the Superior Council of Magistracy - As long as the competence of the President of the Republic relies only on the control of the lawfulness of the revocation procedure, he cannot invoke as a ground for refusal the proposal of the Minister of Justice that the Superior Council of Magistrates - the Prosecutor's Section found that "the issues raised by the Minister of Justice do not reveal deficiencies in the exercise of managerial duties by the Chief Prosecutor of the National Anticorruption Directorate "or that "In the report of the Minister of Justice, the managerial components are generically listed, without a concrete individualization of the unlawfully used resources, behavioral deficiencies, unfulfilled legal attributions or managerial skills that are inexistent or manifestly defective." As has been pointed out, the Superior Council of Magistrates 'Decision Prosecutors' Section is a consultative reference for the Minister of Justice regarding both the legality and the soundness of the proposal, but the President of Romania, given his competence, can also use the consultative value, only on the legality of the procedure.

\section{Short commentary}

\section{The Regulation of the judicial authority in the Romanian Constitution}

The recent Court decision restores the constitutional regulation of the Judicial Authority. Although in current speech, the notion of judicial authority is assimilated to

${ }^{38}$ Of the Minister of Justice.

CONSTITUTIONAL LAW REVIEW 
judicial power, assimilation is incorrect, leading to obvious confusions of constitutional status with respect to the legal professions and the authorities concerned.

Thus, Chapter VI of Title III of the Romanian Constitution, entitled the Judicial Authority, includes: Section I - The Courts; Section 2 - The Public Ministry and Section 3 The Superior Council of Magistracy. It is observed that although Title III of the Constitution regulates public authorities in relation to their functions on the classical structure of the separation of powers in the State, Chapter VI of Title III encompasses both the courts (which represent the judiciary) as well as other authorities, namely the Public Ministry and the Superior Council of Magistracy, brought together under the sign of the phrase judicial authority. Thus, we distinguish, from the beginning, between the judicial power represented by the courts and the judicial authority which includes, together with the courts, the two other mentioned public authorities, namely the Public Ministry and the Superior Council of Magistracy.

The constitutional provisions are developed in a series of organic laws, namely Law no. 303/2004 on the status of judges and prosecutors, Law no. 304/2004 on judicial organization and Law no. 317/2004 on the Superior Council of Magistracy. Regarding the role of each of the mentioned authorities, art. 1 of the Law no. 304/2004 on judicial organization provides as follows: "(1) The judiciary power is exercised by the High Court of Cassation and Justice and by the other courts established by law. (2) The Superior Council of Magistracy is the guarantor of the independence of justice. (3) The Public Ministry shall exercise its powers through prosecutors established in prosecutor's offices, according to the law".

The constitutional norms, as well as their development through the organic laws, constitute essential differences of status between judges and prosecutors, as well as differences resulting from the international documents involved in the matter.

\section{The Status of judges. Justice is provided only by the courts}

According to art. 126 par. (1) of the Romanian Constitution, "Justice shall be administered by the High Court of Cassation and Justice, and the other courts of law set up by the law", and according to art. 126 par. (5), "It is prohibited to establish extraordinary courts of law. By means of an organic law, courts of law specialized in certain matters may be set up, allowing the participation, as the case may be, of persons outside the magistracy". Finally, according to art. 73 par. (3) lit. I) of the Constitution, „Organic laws shall regulate: [...] the organization and functioning of the Superior Council of Magistracy, the courts of law, the Public Ministry, and the Court of Audit". Thus, the Constitution leaves, on the basis of the organic law, the establishment of the jurisdictional levels and the appropriate courts. In this respect, Art. 2 par. (2) of the Law no. 304/2004 on judicial organization provides that "The following courts make up the judicial system: a) the High Court of Cassation and Justice; b) the courts of appeal; c) the tribunals; d) the specialized tribunals; e) the military courts; f) the district courts". 
A special role among the courts is the High Court of Cassation and Justice, as it ensures the unitary interpretation and application of the law by the other courts, according to its competence.

The term justice has two meanings: the judicial system; the activity of solving civil, administrative, commercial, criminal, labor etc. cases, applying sanctions, restoring the violated rights and legitimate interests. The fundamental principles according to which justice is carried out are the following: the independence of the judge, subject only to the law, the principle of legality (in a double sense: the lawfulness of the courts and the lawfulness of the crimes and the punishments), free access to justice, all respecting the right of defense, respecting the presumption of innocence, advertising court hearings, using the official language and the mother tongue in justice.

The judge is therefore the one who benefits from the full independence of the exercise - only by him - of the judiciary power. The principle of judge's independence means that in his or her work, the judge is subject only to the law, i.e. in litigation he cannot receive orders, instructions, indications, suggestions on the solution he has to pronounce. The constituent legislator established the independence of the judge to defend him from the influence of the political authorities and, in particular, of the executive power; this guarantee cannot be interpreted as being such as to determine the lack of accountability of the judge or discretionary attitude on the part of the judge. In this respect, the Constitutional Court of Romania has stated that" The fundamental law does not only give prerogatives - which, in the text mentioned, circumscribe the concept of "independence" - but also establish limits to their exercise - which, in this case, circumscribe the phrase "are subject only to the law". The institutionalization of some forms of accountability of judges gives expression to these limits, in accordance with the requirements of the principle of separation and balance of powers in the state, enshrined in art. 1 par. (4) of the Constitution. One of the forms of judicial, personal and direct liability of the judge is disciplinary liability, which derives from the duty of loyalty to the role and function of the judge, as well as the exigency that he must prove in fulfilling his obligations to the justice and the state "(...)" in the art. 124 of the Constitution, with the marginal name "Enforcement of justice", the text indicated is preceded by two paragraphs, according to which (1) Justice shall be rendered in the name of the law. (2) Justice shall be one, impartial, and equal for all". Thus, it appears that the independence of the judges, both from a functional point of view (in relations with the representatives of the legislative and executive powers), as well as the personnel (that is, the status to be given to the judge by law), represents a guarantee for the performance of justice independent, impartial and equal, in the name of the law. Since justice concerns individuals, all constitutional or infra-institutional guarantees that relate to its implementation serve ultimately to realize their rights and freedoms. In fact, this is the framework in which a number of international documents of constitutional 
interpretative value use the concept of "independent tribunal"39. Constitutional rules include safeguards for the independence of judges, including the conditions for recruitment, irremovability, promotion and sanctioning of judges. Thus, both the recruitment and the promotion of judges are done through competition. The judges appointed by the President of Romania are irremovable. In the jurisprudence of the Constitutional Court, immovability was defined as "that state of law which, in guaranteeing the independence of judges, protects them against the risk of being dismissed, relieved or demoted from office without legitimate reason or moved to other courts by delegation, even by promotion, without their consent. The principle of irremovability applies both to the duration of the judge's function and to the duration of the term of the managerial function performed by the judge, which can neither be reduced nor extended without the consent of the judge" ${ }^{40}$. Non-transferable judges may be moved, transferred, posted or promoted only with their consent and may be suspended or dismissed under the conditions laid down in this present act - Law no. 303/2004. Irremovability protects the judge against arbitrary revocation, transfer, suspension and sanction. This concerns only the quality of judge, not the functions of judicial management.

3. The status of prosecutors. The role of public prosecutors in the Public Ministry, under the authority of the Minister of Justice, is to represent in the judicial activity the general interests of society and to defend the rule of law, the rights and freedoms of citizens

The Public Ministry comprises prosecutors, set up in groups, and is headed by the Prosecutor General of the Prosecutor's Office attached to the High Court of Cassation and Justice. The public ministry does not have any legislative, executive or judicial powers. According to the Romanian Constitution, the Public Ministry is part of the judicial authority and not of the judiciary, and therefore does not exercise this power, nor does it benefit from the specific guarantees of the judiciary power.

The role of the Public Ministry is to represent, in the judicial activity, the general interests of society and to defend the rule of law and the rights and freedoms of citizens. It exercises the following attributions through prosecutors: it carries out the criminal prosecution in the cases and under the conditions stipulated by the law and participates, according to the law, in solving the conflicts by alternative means; conducts and supervises the criminal investigation activity of the judicial police, directs and controls the work of other criminal investigation bodies; notify the courts for the prosecution of criminal cases, according to the law; exercise the civil action in the cases provided by law; participate, under the law, at court hearings; Exercise the remedies

\footnotetext{
${ }^{39}$ Ruling no. 2 of January 11, 2012, published in the Official Gazette of Romania, Part I, no. 131 of 23 February 2012.

${ }^{40}$ Ruling no. 375/2005, published in the Official Gazette of Romania, Part I, no. 591 of 8 July 2005.
}

CONSTITUTIONAL NEWS 
against the court decisions, under the conditions provided by the law; defends the legitimate rights and interests of minors, people under interdiction, displaced persons and other persons under the law; acts for the prevention and combating of crime, under the coordination of the Minister of Justice, for the unitary realization of the state's criminal policy; study the causes that generate or favor crime, develop and submit proposals to the minister of justice for their elimination, as well as for the improvement of the legislation in the field; verifies compliance with the law at places of detention; exercise any other duties provided by law.

The status of the prosecutor differs, therefore, from that of the judge. According to art. 132 of the Romanian Constitution: "(1) Public prosecutors shall carry out their activity in accordance with the principle of legality, impartiality and hierarchical control, under the authority of the Minister of Justice. (2) The office of public prosecutor is incompatible with any other public or private office, except for academic activities." The aspects related to the status of prosecutors are legally explained in Law no. 303/2004 on the status of judges and prosecutors, republished in the Official Gazette of Romania, Part I, no. 826 of 13 September 2005, which stipulates that both professional categories belong to magistrates, defined as the judicial work carried out by judges for the purpose of justice and prosecutors in order to protect the general interests of society, the rule of law and the rights and freedoms of citizens. Distinguishing this aspect between the prosecutor and the judge and the specific guarantees, the Venice Commission noted that «29. A clear distinction has to be made between a possible independence of the prosecutor's office or the Prosecutor General as opposed to the status of prosecutors other than the prosecutor general who are rather 'autonomous' than 'independent'. The prosecutor's offices are often referred to as 'autonomous' and individual prosecutors would be referred to as 'independent'. 30. Any 'independence' of the prosecutor's office by its very essence differs in scope from that of judges. The main element of such "external" independence of the prosecutor's office, or for that of the Prosecutor General, resides in the impermissibility of the executive to give instructions in individual cases to the Prosecutor General (and of course directly to any other prosecutor). General instructions, for example to prosecute certain types of crimes more severely or speedily, seem less problematic. Such instructions may be regarded as an aspect of policy which may appropriately be decided by parliament or government. 31. The independence of the prosecution service as such has to be distinguished from any "internal independence" of prosecutors other than the prosecutor general. In a system of hierarchic subordination, prosecutors are bound by the directives, guidelines and instructions issued by their superiors. Independence, in this narrow sense, can be seen as a system where in the exercise of their legislatively mandated activities prosecutors other than the prosecutor general need not obtain the prior approval of their superiors nor have their action confirmed. Prosecutors other than the prosecutor general often rather enjoy guarantees for noninterference from their hierarchical superior. 32. In order to avoid undue instructions, it is essential to develop a catalogue of such guarantees of 
non-interference in the prosecutor's activities. Non-interference means ensuring that the prosecutor's activities in trial procedures are free of external pressure as well as from undue or illegal internal pressures from within the prosecution system. Such guarantees should cover appointment, discipline/removal but also specific rules for the management of cases and the decision-making process" ${ }^{\prime 1}$.

The Public Ministry is independent in relations with the other authorities, and the constitutional principles of its organization and functioning are: legality, impartiality, hierarchical control. Thus, the prosecutors in each prosecutor's office are subordinated to the head of the respective prosecutor's office. The leader of a parquet is subordinated to the superior hierarchical prosecutor in the same constituency. The control exercised by the Prosecutor General of the Prosecutor's Office attached to the High Court of Cassation and Justice, the Chief Prosecutor of the National Anticorruption Directorate or the Prosecutor General of the Prosecutor's Office attached to the Court of Appeal on subordinated prosecutors may be directly or through designated prosecutors. Prosecutors appointed by the President of Romania enjoy stability and are independent, under the law. Prosecutors enjoying stability may be moved, transferred or promoted only with their consent. They may be delegated, suspended or dismissed under the conditions laid down by law.

Decision No. 358/2018 also necessitated a clarification and the phrase that places prosecutors under the authority of the Minister of Justice, as is apparent from the in extenso considerations.

\section{Superior Council of Magistracy - guarantor of the independence of justice}

The main functions of the Superior Council of Magistracy, in accordance to the constitutional reference provisions, are the following: proposing to the President of Romania the appointment of judges and prosecutors in office, except for the trainees; performing the role of a court in the field of disciplinary liability of judges and prosecutors.

The Superior Council of Magistracy is made up of 19 members, of which: 14 are elected in the General Assemblies of Magistrates and validated by the Senate; 2 representatives of civil society, specialists in the field of law, who enjoy high professional and moral reputation, elected by the Senate; the Minister of Justice, the President of the High Court of Cassation and Justice and the Prosecutor General of the Prosecutor's Office attached to the High Court of Cassation and Justice. The term of office of the members of the Superior Council of Magistracy is 6 years.

The Superior Council of Magistracy functions as a permanent body. Decisions of the Superior Council of Magistracy shall be taken in plenary or in sections, according to their attributions. The proceedings of the Plenum of the Superior Council of Magistracy are carried out in the presence of at least 15 members, and the works of the sections are

\footnotetext{
${ }^{41}$ Report on European Standards on Judicial Independence: Part II - Criminal Investigation Bodies - Adopted by the Venice Commission at its $85^{\text {th }}$ plenary session, Venice, 17-18 December 2010.
}

CONSTITUTIONAL NEWS 
carried out in the presence of the majority of their members. The decisions of the Plenum of the Superior Council of Magistracy and the decisions of the sections shall be taken by the vote of the majority of the present members.

The President of the High Court of Cassation and Justice participates in the work of the Section for Judges, the Prosecutor General of the Prosecutor's Office attached to the High Court of Cassation and Justice, to the Prosecutor's Office and the Minister of Justice to the works of both sections. The President of the High Court of Cassation and Justice, the Minister of Justice and the Prosecutor General of the Prosecutor's Office attached to the High Court of Cassation and Justice shall not have the right to vote in cases where the units fulfill the role of a court in the field of disciplinary liability, when solving complaints regarding the good reputation of judges and prosecutors, and requests for permission to search, detention, pre-trial detention or home arrest in respect of judges, prosecutors or assistant magistrates. Representatives of civil society participate only in the work of the Plenum of the Superior Council of Magistracy.

The Superior Council of Magistracy has the right and duty to appeal also ex officio to defend judges and prosecutors against any act that could affect their independence or impartiality or raise suspicions about them. The Superior Council of Magistracy also defends the professional reputation of judges and prosecutors. It also ensures compliance with the law and the criteria of professional competence and ethics in the professional career of judges and prosecutors, draws up and maintains the professional files of judges and prosecutors.

\section{Conclusions}

According to Article 1 of the Constitution, Romania is a state of law. Characterizing this concept in several rulings, the Constitutional Court of Romania ruled that "its demands regard the major goals of state activity, prefigured in what is commonly called the rule of law, a phrase involving the subordination of the state to the law, providing the means to allow the law to censor political choices and, in this context, to balance out the eventual abusive, discretionary tendencies of the state structures. The rule of law ensures the supremacy of the Constitution, the correlation of laws and all normative acts with it, the existence of the regime of separation of public powers, which must act within the limits of the law, namely within the limits of a law expressing the general will. The rule of law enshrines a series of safeguards, including jurisdictional, to ensure respect for the rights and freedoms of citizens through the state's self-restraint, namely the assignment of public authorities to the coordinates of law" ${ }^{\prime 2}$. It is also an approach developed in international documents such as the RULE OF LAW CHECKLIST adopted by the Venice Commission at its $106^{\text {th }}$ Plenary Session (Venice, 11-12 March 2016).

The rule of law is plenary when all public authorities, whether within the sphere of the judiciary or outside it, observe and are framed in the coordinates of law, and they respect their constitutional and legal competences.

\footnotetext{
42 See Ruling no. 70 of 18 April 2000, The Official Gazette of Romania no. 334 of 19 July 2000 or Ruling no. 17 of January 21, 2015, The Official Gazette of Romania no. 79 of January 30, 2015.
}

CONSTITUTIONAL LAW REVIEW 